\title{
Bole rot of sisal caused by Aspergillus niger in Brazil
}

\author{
Wirton M. Coutinho ${ }^{1}$, Nelson D. Suassuna ${ }^{1}$, Clarice M. Luz ${ }^{2}$, \\ Fábio A. Suinaga ${ }^{1}$ \& Odilon R.R.F. Silva ${ }^{1}$ \\ 'Embrapa Algodão, Cx. Postal 174, CEP 58107-720, Campina Grande, PB, e-mail wirton@enpa.embrapa.br; \\ ${ }^{2}$ Departamento de Biologia, Universidade Estadual da Paraíba, CEP 58109-753, Campina Grande, PB
}

(Aceito para publicação em 21/11/2006)

Autor para correspondência: Wirton Macedo Coutinho

\begin{abstract}
RESUMO
Podridão do tronco do sisal causada por Aspergillus niger no Brasil

A ocorrência da podridão do tronco do sisal, causada por Aspergillus niger, é relatada pela primeira vez no Brasil. A doença foi observada em campos de produção nos Estados da Bahia, Paraíba e Rio Grande do Norte.
\end{abstract}

\begin{abstract}
Sisal (Agave sisalana Perrine ex. Engelm.) is the world major source of vegetal hard fibers. Processed sisal fibers are used to make twine, cord, carpets, bags and hats. This plant is cultivated in Brazil in soils with low fertility in semi-arid regions of Bahia, Paraíba and Rio Grande do Norte States. In these regions, more than half a million people work in the sisal supply chain. In recent inspections in the sisal fields of Monteiro and Pocinhos Counties (Paraíba State) and Santa Luz County (Bahia State), sisal plants with bole rot were observed (Figure 1A). The internal tissues were brown, surrounded by a reddish border (Figure 1B). After two to three months the rot can spread into the entire region below the meristem, making it appear soaked with water. The leaves turn yellow and collapse when the bole is completely rotten. Disease incidence can vary from $5 \%$ to $40 \%$ in the production areas. To determine disease etiology, margin fragments from affected bole tissues were cut, disinfected in $1 \%$ sodium hypochlorite for 1 minute, rinsed in sterile water and plated on PDA (Potato - Dextrose - Agar) medium. The colonies were initially white, but turned black with conidial production after five days at $25{ }^{\circ} \mathrm{C}$ under cool fluorescent lamps and a 12-hour photoperiod (Figure 1C). The morphological characteristics permitted identification of the pathogen as Aspergillus niger Tiegh. (Thom \& Raper, 1945. A Manual of Aspergilli). Hyphae were septate and hyaline; conidial heads were initially radiate, splitting into columns at maturity; conidiophores were long (250-360 $\mu \mathrm{m} \times 6-8 \mu \mathrm{m})$, smooth, hyaline, becoming darker at the apex with a globose vesicle (20-40 $\mu \mathrm{m}$ in diameter); metulae and phialides covered the entire vesicle; conidia were brown to black, rough, globose, 3-5 $\mu \mathrm{m}$ in diameter. The pathogenicity test was done by inoculating the bole of sisal plants with a conidial suspension adjusted to $3.0 \times 10^{5}$ spores $/ \mathrm{mL}$ of three isolates of $A$. niger (CNPA 0020, CNPA 0021, CNPA 0036). Inoculation was performed on wounded and unwounded eight-months-old sisal basal leaves, using a cotton swab soaked in conidial suspension. The wound was made by cutting sisal basal leaves with a sterilized scalpel. The controls were sisal plants inoculated with a cotton swab soaked in distilled water. After inoculation the plants were placed in a growth chamber for four days at $25 \pm 2{ }^{\circ} \mathrm{C}$
\end{abstract}

and relative humidity between 95 and $100 \%$. After this period the plants were placed in a greenhouse for ten days, where the first symptoms were observed on wounded plants (Figure 1D). After one month, sisal plants were transversally cut and typical symptoms were observed (Figure 1E). No symptoms were observed on unwounded and control plants. Disease etiology was confirmed by reisolating the fungus on PDA. The bole rot of sisal, caused by A. niger, was first reported in 1952 in Tanzania, in central-east Africa (Wallace \& Diekmahns. The East African Agricultural Journal 18:24. 1952). This is the first report of bole rot of sisal caused by $A$. niger in Brazil.

\section{ACKNOWLEDGEMENTS}

The authors thank Fundo Científico e Tecnológico (FUNDECI) of Banco do Nordeste do Brasil (BNB) for financial support.

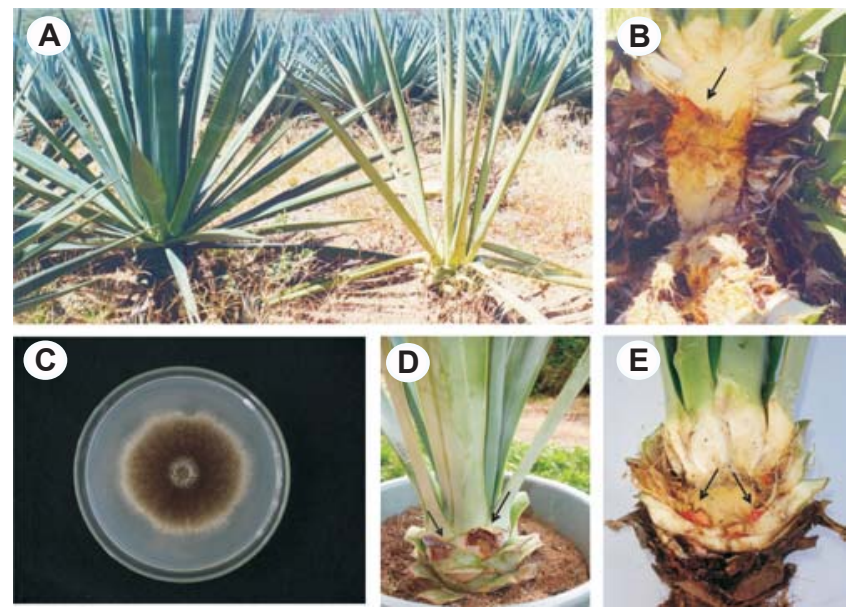

FIG. 1 - A. Healthy Agave sisalana (left) and A. sisalana with bole rot (right); B. Internal symptoms of bole rot of A. sisalana, C. colonies of Aspergillus niger on PDA medium; D. E. symptoms on wounded A. sisalana, inoculated with $A$. niger. 